Portland State University

PDXScholar

\title{
A Case for Collaborative Resource Management: Comparative Analysis of Public Resources to Establish Fish Consumption Advisories in the Pacific Northwest
}

Alyssa Clayton

Portland State University

Follow this and additional works at: https://pdxscholar.library.pdx.edu/honorstheses Let us know how access to this document benefits you.

\section{Recommended Citation}

Clayton, Alyssa, "A Case for Collaborative Resource Management: Comparative Analysis of Public Resources to Establish Fish Consumption Advisories in the Pacific Northwest" (2017). University Honors Theses. Paper 482.

https://doi.org/10.15760/honors.485

This Thesis is brought to you for free and open access. It has been accepted for inclusion in University Honors Theses by an authorized administrator of PDXScholar. Please contact us if we can make this document more accessible: pdxscholar@pdx.edu. 
A Case for Collaborative Resource Management: Comparative Analysis of Public Resources to Establish Fish Consumption Advisories in the Pacific Northwest

by

Alyssa Clayton

An undergraduate honors thesis submitted in partial fulfillment of the requirements for the degree of

Bachelor of Science

in

University Honors

and

Environmental Studies

Thesis Adviser

Dr. Karen Watanabe

Portland State University

2017 


\section{Abstract}

Fish consumption advisories (FCAs) are intended to protect the public from toxicants, such as methylmercury, that bioaccumulate in fish tissues. Women of childbearing age, children and subsistence fishers are particularly vulnerable to methylmercury exposure, as it is a known neurotoxin that harms the central nervous system. Resources, collaboration and protocols to establish FCAs vary from state to state. This study examines resources available to states in the Pacific Northwest to develop and institute statewide largemouth bass (Micropterus salmoides) and smallmouth bass (Micropterus dolomieu) advisories. Similarities and differences are identified between public agencies that facilitate FCAs in Oregon, Washington and Idaho. My findings revealed funding and collaboration between federal and state agencies is inconsistent, as long-term, direct funding mechanisms do not exist for personnel, sampling and laboratory analyses, impacting the ability to establish and update advisories. I recommend increased funding and data sharing amongst agencies, standardized reporting of fish tissue data, and formalized collaborative governance amongst federal and state agencies to ensure consistent and long-term support of FCAs.

Introduction

Mercury is a toxic heavy metal found in the atmosphere, thermometers, dental amalgams, vaccine preservatives, and fish. It bioaccummulates in fish tissue, concentrating in predators such as largemouth bass (Micropterus salmoides) and smallmouth bass (Micropterus dolomieu) (Peterson et al., 2007). The majority (9599\%) of mercury accumulated in fish tissue is in the form of methylmercury (Grieb 
et al., 1990). Methylmercury is a known neurotoxin. Women of childbearing age and children are especially vulnerable to methylmerucy as it is linked to impairment of the developing central nervous system in addition to nephrotic and pulmonary damage (Counter and Buchanan, 2004). Exposure is most commonly the result of consumption of fish. The Environmental Protection Agency (EPA) issued water quality criteria under the Clean Water Act, the protection of aquatic communities and human health related to fish consumption is referred to in section 303(d) impaired waters and total maximum daily load (EPA, 2017). This designation is intended as guidance for states to establish fish consumption advisories and protect communities from methylmercury exposure (FCA) (EPA, 2017).

When examining the effectiveness of FCAs, studies have found awareness of FCAs is low among women of childbearing age, with awareness ranging between $8 \%$ $-32 \%$ of respondents (Park and Johnson, 2006). In Kashian and colleagues' study on stakeholder participation around the Detroit River, they define stakeholders as public, private or community organizations directly or indirectly involved in FCAs (Kashian et al., 2014). They investigated whether or not advisory information is reaching target populations and to what extent stakeholders are involved in the data collection and implementation of FCAs (Park and Johnson, 2006; Kashian et al., 2014). This study focuses on public stakeholders, specifically the interaction of state public health agencies and their dependence and collaboration with other state and federal agencies. Where other studies (Kashian et al., 2014; Gerlak and Heikkila, 2006) compared a breadth of stakeholder objectives and collaboration, they did not compare public resources from state to state to establish FCAs. Public stakeholders 
are responsible for issuing FCAs; their resources influence availability of fish tissue data and public awareness of toxic exposure from fish consumption.

FCAs issued by states apply to non-commercial fish and shellfish caught for recreation, sport and subsistence (EPA, 1999; Park and Johnson, 2006). Monitoring and consumption criteria vary from state to state (Chess and McDermott, 2007). Chess and McDermott found variability in FCA reporting caused interagency conflict in South Carolina and Georgia. The states used the same fish tissue monitoring dataset on contaminant concentrations but risk assessments were computed with different assessment hazards and rates of consumption (Chess and McDermott, 2007). As a result, South Carolina issued a FCA and Georgia did not (Chess and McDermott, 2007). The release of an FCA for both states did not occur until Georgia was pressed into it by university researchers and the EPA (Chess and McDermott, 2007). Conflict may occur between state agencies if one objective inhibits another, such as promoting tourism and protecting public health. An example of this may occur when a fish and game agency encourages fishing, and a health agency issues consumption advisories.

Little data are available on the number of people that regularly consume smallmouth bass and largemouth bass in the Pacific Northwest. Fishing licenses are not indicative of how many people consume the species. Lack of consumption rate data should not preclude environmental monitoring from taking place nor FCAs from being published. This is especially important when considering that marginalized populations such as immigrants and homeless residents are part of the 
subsistence fishing demographic. Subsistence fishers, indigenous tribes, women of child bearing age and children are the most vulnerable to methylmercury exposure because of their rate of exposure and the deleterious impact methylmercury has on development. This is a circumstance where it is best to take precaution.

FCAs span multiple jurisdictional boundaries, involving a varied group of public stakeholders. To ensure long-term resources for FCAs, the integration of collaborative resource governance would significantly augment resource limitations and encourage accountability, as multiple parties would have responsibility to facilitate FCAs. Gerlak and Heikkila (2006) define collaborative resource governance as "a group of diverse stakeholders, including resource users and government agencies, working together to resolve shared dilemmas. " This collaborative framework promotes participation, policy dialogue and fosters trust amongst participants (Gerlak and Hekkila, 2006). In addition, this model has the potential to improve individual resource limitations, as funding and labor are not distributed equally amongst agencies, limiting the burden of individual FCA objectives.

In Gerlak and Heikkila's research, they examine large scale, collaborative resource governance by institutions focusing on the Northwest Power and Conservation Council's Fish and Wildlife Program in the Columbia River Basin. The Northwest Power and Conservation Council's Fish and Wildlife Program dates back to 1980 ; it was formed in response to the increasing augmentation of the Columbia river for hydropower and irrigation in the last century (Gerlak and Heikkila, 2006). The council is an interstate collaborative resource management governing body 
between Oregon, Washington, Idaho and Montana to facilitate energy conservation and wildlife protection in the Columbia River Basin. The Bonneville Power administration, Columbia Inter-Tribal fish commission and the Pacific fisheries management council are also involved in the council (Gerlak and Heikkila, 2006). On a smaller scale, I apply the collaborative resource governance model to recommend public resource management for FCAs in the Pacific Northwest.

Mullin and Daleys' research on interagency collaboration within a federalist system found that performance evaluations tied to collaborative efforts are the strongest determinant of collaboration across all levels of government (Mullin, 2009). Their research focuses on the relationship between local, state and federal collaborative efforts. Mullin and Daley found agencies are more likely to work together if they lack the capacity to act alone (Mullin and Daley, 2009). Before performance evaluations for accountability can be established, a formal agreement or memorandum must be put into place to solidify a collaborative relationship. This study informed my inquiry into whether or not state and federal agencies have a formal collaborative agreement in place in Oregon, Idaho and Washington to facilitate FCAs.

Formal collaboration agreements facilitate sharing of environmental monitoring data, such as fish tissue and water quality data. The Pacific Northwest currently does not have a shared database for fish tissue data; states share and access information within their jurisdictions. Cooter and colleagues' research identified the need to standardize approaches for evaluating risks and developing 
FCAs that are comparable across jurisdictions (Cooter et al., 2009). They found that the application of national benchmarks helps to leverage programs involving state environmental, public health and natural resource agencies with responsibilities over toxic contaminants in fish tissues (Cooter et al., 2009). A database available to the public would strengthen these aims and foster transparency amongst stakeholders. Cooter and colleagues' research informed my decision to identify standardized methods for sampling and analysis of fish tissue as well as the procedures for making risk management decisions.

My objective is to compare public resources in Oregon, Washington and Idaho to establish statewide bass consumption advisories. Resource parameters examined include establishment of long term funding mechanisms, federal and state agency partners, number of full time staff responsible for FCAs, whether or not collaboration is formalized between agencies, if data sharing occurs, whether sampling methodology is consistent as well as what the protocols are to survey and collect fish tissue data across states. Through the comparison of state resources, I identify strengths and limitations of existing resources to establish FCAs. Finally, I argue FCAs would benefit from the integration of collaborative resource governance amongst public stakeholders.

Methods

During the summer of 2015, I interned with Oregon Health \& Science University's (OHSU) Institute of Environmental Health; I worked with Oregon Health Authority (OHA), to calculate a statewide largemouth bass and smallmouth bass consumption advisory. I assembled fish tissue data from state and federal 
agencies, evaluated it based on data quality criteria, compiled it and calculated a consumption recommendation. OHA published the results of the FCA in the spring of 2016 (Oregon Public Health Division, 2016). This endeavor was the catalyst for the comparison of public resources to establish bass FCAs in the Pacific Northwest.

I relied on contacts at OHA, the Washington State Department of Health (WDOH) and Idaho Division of Public Health (IDPH) to collect and report public resources such as: funding mechanisms for FCAs, state and federal agency partners, number of full time staff responsible for FCAs, existence of formalized channels of communication and data sharing across agencies. In addition, I captured information on sampling methodologies in each state, number of data points integrated into a fish advisory and whether or not a standardized sampling protocol exists to collect fish tissue data. The outcome of these inquiries is available below in Table 1.

I collected information on funding mechanisms to identify whether financial resources are in place to regularly update FCAs in each state. Number of state and federal agency partners is meant to inform existing scholarship on collaboration and decision making progress to establish FCAs by public entities in Oregon, Washington and Idaho as well as bolster my argument for the integration of collaborative management strategies into government decision making processes. The number of full time staff reveals how much public labor is invested in bass FCAs. Formalized communication indicates regularity and obligation to data collection and sharing amongst state and federal agencies. Sampling methodology impacts quality of the final FCA calculation and is indicative of monetary resources. Data points integrated 
into consumption advisories and standardized sampling protocols are listed to indicate resources available to establish FCAs and to reveal how thorough they are as well as how easily they can be compared across states and over time. Inability to compare data weakens the capability to analyze trends overtime and justify the inclusion of fish tissue data into advisories. In the most recent statewide bass FCA calculated in Oregon, datasets provided for total mercury spanned as far back as the early 1970s. However, mercury data collected prior to 2008 were not integrated into the advisory because of failure to meet data quality criteria. 
Results

Table 1. Comparison of public resources (funding mechanisms, staff) and interagency collaboration (federal and state partners, communication and data sharing) to establish state bass consumption advisories in Oregon, Idaho, and Washington. State agencies with an asterisk next to their name are responsible for FCAs in each state.

\begin{tabular}{|c|c|c|c|c|c|c|}
\hline State & $\begin{array}{c}\text { Long term } \\
\text { funding } \\
\text { mechanism } \\
\end{array}$ & State agency partners & $\begin{array}{c}\text { Federal agency } \\
\text { partners }\end{array}$ & $\begin{array}{c}\text { \# of Full time } \\
\text { staff updating } \\
\text { advisories }\end{array}$ & $\begin{array}{l}\text { Communication } \\
\text { amongst agencies }\end{array}$ & $\begin{array}{c}\text { Data sharing } \\
\text { amongst } \\
\text { agencies }\end{array}$ \\
\hline Idaho (ID) & None & $\begin{array}{l}\text { 1. Idaho Division of Public } \\
\text { Health* } \\
\text { 2. Idaho Department of Fish } \\
\text { and Game } \\
\text { 3. Idaho Department of } \\
\text { Environmental Quality }\end{array}$ & $\begin{array}{l}\text { 1. Environmental } \\
\text { Protection Agency } \\
\text { 2. United States } \\
\text { Geological Survey }\end{array}$ & Not available & $\begin{array}{c}\text { Idaho Fish } \\
\text { Consumption } \\
\text { Advisory Project }\end{array}$ & Yes \\
\hline Oregon (OR) & $\begin{array}{l}\text { Drinking } \\
\text { Water } \\
\text { Program }\end{array}$ & $\begin{array}{l}\text { 1. Oregon Health Authority* } \\
\text { 2. Oregon Department of } \\
\text { Environmental Quality } \\
\text { 3. Oregon Department of } \\
\text { Agriculture } \\
\text { 4. Oregon Department of Fish } \\
\text { and Wildlife }\end{array}$ & $\begin{array}{l}\text { 1. Environmental } \\
\text { Protection Agency }\end{array}$ & $\begin{array}{l}0.375 \text { indirect } \\
\text { full time } \\
\text { equivalents }\end{array}$ & $\begin{array}{l}\text { No formal } \\
\text { communication } \\
\text { plan, } \\
\text { Memorandum of } \\
\text { understanding, in } \\
\text { progress, Stream } \\
\text { team }\end{array}$ & $\begin{array}{c}\text { Yes; Oregon } \\
\text { Govspace data } \\
\text { sharing } \\
\text { platform }\end{array}$ \\
\hline $\begin{array}{l}\text { Washington } \\
\text { (WA) }\end{array}$ & $\begin{array}{c}\text { Model Toxics } \\
\text { Control Act } \\
\text { (MTCA) }\end{array}$ & $\begin{array}{l}\text { 1. Washington State } \\
\text { Department of Ecology } \\
\text { 2. Washington Department of } \\
\text { Fish and Wildlife } \\
\text { 3. Washington Department of } \\
\text { Health* }\end{array}$ & $\begin{array}{l}\text { 1. Environmental } \\
\text { Protection Agency } \\
\text { 2. United States } \\
\text { Geological Survey } \\
\text { 3. United States } \\
\text { Department of Energy } \\
\text { 4. United States } \\
\text { Department of Interior }\end{array}$ & $\begin{array}{c}1 \text { Indirect, Full } \\
\text { Time } \\
\text { Employee }\end{array}$ & $\begin{array}{l}\text { No formal } \\
\text { communication } \\
\text { plan, collaboration } \\
\text { on a interpersonal, } \\
\text { ad hoc basis }\end{array}$ & $\begin{array}{c}\text { Yes; } \\
\text { Environmental } \\
\text { Information } \\
\text { Management } \\
\text { data sharing } \\
\text { platform }\end{array}$ \\
\hline
\end{tabular}

\begin{tabular}{|c|c|c|c|}
\hline State & Sampling methodology & $\begin{array}{c}\text { Data points integrated into } \\
\text { advisory }\end{array}$ & $\begin{array}{c}\text { Sampling breadth, survey } \\
\text { protocol }\end{array}$ \\
\hline Idaho (ID) & Composite and Individual & Unknown & $\begin{array}{c}\text { Ad Hoc, Quality Assurance Protocol } \\
\text { adhered to }\end{array}$ \\
\hline Oregon (OR) & Composite and Individual & 62 & $\begin{array}{l}\text { Ad hoc, Quality Assurance Protocol } \\
\text { adhered to }\end{array}$ \\
\hline Washington (WA) & Composite and Individual & Unknown & $\begin{array}{l}\text { Ad hoc, Quality Assurance Protocol } \\
\text { adhered to }\end{array}$ \\
\hline
\end{tabular}

(Farrer 2017; McBride, 2017; Vannoy, 2016; Adams 2017) 
Summary of data in Table 1:

In Idaho, there is no funding source for FCAs (Vannoy, 2016; Adams, 2017). The ID Division of Public Health, ID Department of Fish and Game and ID Department of Environmental Quality, EPA and USGS collaborate to address fish tissue monitoring, analysis and communication with the public (Vannoy, 2016; Adams 2017). Together, they comprise the Idaho Fish Consumption Advisory Program (Idaho Department of Health and Welfare, 2017). The number of full time staff working on FCAs in Idaho was not unavailable. Data sharing occurs between agencies; the existence of a shared database was not reported. Composite and individual sampling of fish tissue data is integrated into FCAs. The number of data points integrated into is unknown. Sampling is conducted on an ad hoc basis; quality assurance protocols are adhered to across agencies. Jim Vannoy, my primary contact with the ID Division of Public Health retired while I collected information for this analysis in August 2016. Dr. Colby Adams, his replacement, verified ID FCA information reported in this study in August 2017.

The WDOH receives funding indirectly for FCAs through the Model Toxics Control Act (MTCA) (McBride, 2017); it is tied to a tax on hazardous substances, which funds water quality monitoring. Fish tissue monitoring is conducted as a surrogate for water quality in WA (McBride, 2017). WDOH partners with the WA Department of Fish and Wildlife, WA Department of Health, EPA, USGS and US Department of Energy and US Department of Interior to establish FCAs. Indirectly, through the MTCA, 1 full time employee works on FCAs statewide. No formal communication plan exists amongst agencies; collaboration is on an interpersonal, 
ad hoc basis (McBride; 2017). Fish tissue data is shared through the environmental information management platform, facilitated by the WA Department of Ecology. WDOH integrates composite and individual fish tissue data into FCAs. Sampling is conducted on an ad hoc basis; quality assurance protocols are adhered to across agencies.

Oregon receives funding for FCAs indirectly through the state's drinking water program (Farrer, 2017). OHA collaborates with the OR Department of Environmental Quality, OR Department of Agriculture, OR Department of Fish and Wildlife and EPA to establish FCAs. The state receives indirect funding to support approximately 0.375 full time equivalents for FCAs (Farrer, 2017). When asked to comment on the FCAs and state resources, Farrer emphasized OHA needed a half time person dedicated to FCAs; there is currently no official staff position to generate FCAs statewide (Farrer, 2017). Agencies currently do not have a formal communication plan but, a memorandum of understanding is being developed to facilitate long-term collaboration. OHA is dependent on other state and federal agencies (mainly the OR Department of Environmental Quality and EPA) to obtain fish tissue data (Farrer, 2017). Agencies share data via Oregon Govspace, an online database. OHA incorporates composite and individual samples fish tissue samples into their FCAs. 62 data points were incorporated in the most recent bass advisory (Oregon Public Health Division, 2016). Oregon's sampling protocol is on an ad hoc basis, quality assurance protocols are used to screen data.

In addition to information presented in Table 1, contacts at $\mathrm{OHA}$ and WDOH responded to an extended survey (See Appendix A) on the categories in Table 1 and 
commented on their role in the decision making process to establish FCAs. In Appendix A, question 10, I inquired if state employees have decision making power to negotiate their responsibilities, advocate for public resources and address underfunding to improve FCAs. McBride, at WDOH, responded

Yes and no. Back in the early 2000s, our fish advisory program had 7-8 people involved in various aspects. Due to changes in agency priorities, retirements, as well as decreases in MTCA funding, Washington has one person working on fish advisories along with other duties. I have made the case to upper management several times that if DOH is concerned about chronic, low-level exposure to many of the contaminants that toxicologist consider to be the worst of the worst, we must address contaminants in fish because that is often the single largest source of exposure the public has to these contaminants (e.g. mercury, PCBs, DDT, etc.). Currently there are no plans at strengthening the fish advisory program such as it is in Washington State.

(McBride, 2017)

The FCA program in WA has experienced reduced funding and monitoring power since the early 2000s and decision-making power on the part of staff is unclear. There is no formal fish advisory program in Washington and a reduction in staff and funding through MTCA exacerbates limitations to update them. At OHA, Farrer informed me that employees could propose policy option packages (POPs) that are reviewed by agency leadership (Farrer, 2017). POPs are requests for general state funds for the purpose described in the POP. If approved, POPs go to the legislature for a vote through the governor's office (Farrer, 2017).

In Appendix A, question 11, I asked employees to comment on the importance of integrating a variety of stakeholders into the environmental monitoring decision making process. Both McBride and Farrer emphasized including tribal communities, as they are dependent on access to healthy fish for nutritional, economic and cultural purposes (Farrer, 2017; McBride, 2017). A 
balanced decision making approach is important to implementing FCAs because they address contaminants that pose the greatest risk to the population (McBride, 2017). Fish often provide some of the highest levels of health promoting omega-3 fatty acids, high quality protein and other nutrients (McBride, 2017). Prevalence of local fish consumption throughout the Pacific Northwest by populations such as tribal communities highlights the importance of continued fish tissue monitoring and FCAs.

Discussion

State agencies in the Pacific Northwest lack consistent funding and resources from year to year to collect and evaluate fish tissue data to publish and update FCAs. This is especially of concern as vulnerable as indigenous populations, subsistence fishers, women of childbearing age and children are the most vulnerable to methylmercury and other chemical exposures. The demographics of the population most vulnerable to toxic exposure make the lack of funding for FCAs an environmental justice concern. Public health advisories such as FCAs must be issued, updated and allocated long-term funds in order to protect the most marginalized and vulnerable of our society.

Based on survey information collected for three states in the Pacific Northwest, agency limitations are exacerbated by lack of formal communication mechanisms, preventing a system of collaboration and accountability from being established beyond an ad hoc basis. Lack of institutional formality makes it difficult for federal and state agencies to collaborate consistently and hold each other accountable for shared responsibilities (Mullin, 2009). Without formal agreements 
to collaborate, it is difficult to create incentives to share data regionally and nationally. Inability to incentivize the creation of shared fish tissue-monitoring database throughout the Pacific Northwest makes it difficult secure funds for future FCAs. In other states, shared databases have been used successfully to secure the necessary resources for state public health programs (Cooter et al., 2009). Lack of formal collaboration, however, prevents from being obtained to establish FCAs.

When employees were asked to comment on their role in securing resources for FCAs, Mcbride at WDOH commented on the decrease in funds for FCAs in the last couple decades, which reduced the number of staff working to implementing them overtime. WDOH has experienced a decrease in personnel for FCAs from 7-8 full time employees to 1 currently. Mcbride commented that he made the case to upper management that they need to invest in fish tissue monitoring, yet there is no plan to strengthen the fish advisory program in Washington State. From a collaborative resource management perspective, top-down decision-making is deaf to concerns from public employees on the issue of methylmercury exposure in Washington State. It is unclear how much influence or decision-making power state employees have at WDOH to improve public health programs.

In Oregon, at OHA, employees can propose POPs to the governor, that if approved are then voted upon in the state legislature to secure funds for public health programs such as FCAs. Although democratic, this method of decisionmaking does not necessarily reflect decision-making power on the part of state agencies to secure funds for themselves, beyond imploring state government do so. Since OHA is limited in their ability to secure funds for increased fish tissue 
monitoring and currently have no established formal communication protocol to work with other state and federal agencies, this impairs their ability to work towards meaningful change with stakeholders outside of state and federal governance. The structure of top-down decision-making in Oregon and Washington obstructs the ability of public stakeholders in Oregon and Washington from establishing collaborative resource management institutions.

In Idaho, long term funding for FCAs and the Idaho Fish Consumption Advisory project is not available. Sampling methodology, survey breadth and quality assurance protocols are consistent amongst the three states. No shared database for fish tissue data was reported for the state of Idaho, though agencies do share data. No information was reported in Idaho pertaining to the influence employee have in the decision-making process and establishment of FCAs. For comparison, information reported on the number of agency collaborations and the existence of a funding mechanism was important to include in this study.

This research could be improved through the expansion of agency contacts and interviews concerning fish tissue data collection and FCA resources at both the state and federal level. Reliance on three health department contacts limits the breadth of information of captured. The review of federal regulatory material on FCAs was significantly compromised by administration changes at the federal level, after the 2016 presidential election. Many of the materials cited from the EPA were inconsistently available post-election. In addition, there were limitations on the part of agency contacts, as FCA information was not always accessible by each health 
agency due to the monitoring responsibilities being spread out amongst different state departments.

Conclusion

Methylmercury exposure is most commonly from fish consumption, yet agencies responsible for FCAs for smallmouth and largemouth bass in Oregon, Washington and Idaho lack resources to monitor, update and publish advisories on a regular basis. This is an environmental justice concern as indigenous populations, subsistence fishers, women of childbearing age and children are most vulnerable to methylmercury exposure. The Washington Department of Health, Oregon Health Authority and Idaho Division of Public Health do not have consistent funding mechanisms in place to establish FCAs. Furthermore, there is no formal communication protocol or governing body amongst state agencies and no funding resources to facilitate collaboration or accountability.

To combat resource limitations it is imperative that public stakeholders establish formal communication protocols and create a shared database available to the public with standardized reporting of fish tissue data. The implementation of formalized communication protocols would distribute responsibility for FCAs beyond health departments and pool more public resources together for environmental monitoring. 


\section{References}

Adams, Colby "Re: Idaho Fish Consumption Advisories” Message to Alyssa Clayton. August 17 2016. Personal communication.

Chess, Caron, and McDermott, Melanie. Speaking Like a State: Environmental Justice and Fish Consumption Advisories. Society \& Natural Resources. 2005.

Cooter, William, Cunningham, Patricia, Rineer, James, Bergenroth, Brandon and Lin, Shu-Yi. A Nationally Consistent Framework for Identifying Interstate Waters with Applications for the National Listing of Fish Advisories. Environmental Monitoring and Assessment. 2010. 172, 1-4 67-89.

Counter, S. Allen, and Leo H. Buchanan. Mercury Exposure in Children: A Review. Toxicology and Applied Pharmacology. 2004. 198.2 209-30.

Farrer, David G. "Re: PSU/Bass consumption advisory thesis/Follow up." Message to Alyssa Clayton. 3 March 2017. Personal communication.

Gerlak, Andrea and Heikkila, Tanya. Comparing Collaborative Mechanisms in LargeScale Ecosystem Governance. Natural Resources. 2006. 46, 657.

Grieb, T. M., Driscoll, C. T., Gloss, S.P., Scholfield, C.L., Bowie, G.L., and Porcella, D.B. Factors affecting mercury accumulation in fish in the Upper Michigan Peninsula. Environmental Toxicology and Chemistry. 1990, 9, 919-930.

Kashian, Donna R., Krause, Ann E., Sano, Larissa, Nowell, Branda and Drouillard, Ken G. Capacity Building in Stakeholders around Detroit River Fish Consumption Advisory Issues. Freshwater Science. 2014. 33.2 674-78.

McBride, David. "Re: PSU/Bass consumption advisory thesis/Follow up." Message to Alyssa Clayton. 7 March 2017. Personal communication.

Mullin, Megan, and Daley, Dorothy. Working with the State: Exploring Interagency Collaboration within a Federalist System. Journal of Public Administration Research and Theory. 2009. 20.4 757-78.

Oregon Public Health Division. Technical Report: Oregon Statewide Bass Fish Consumption Advisory Due to Mercury Contamination. Oregon Health Authority. 2016. Accessed 15 March 2016. Available at http://www.oregon.gov/oha/ph/HealthyEnvironments/Recreation/FishCo nsumption/Documents/TechnicalReportStatewideBassFishConsumptionAdvisory.pdf. 
Park, Sohyun, and Johnson, Mary Ann. Awareness of Fish Advisories and Mercury Exposure in Women of Childbearing Age. Nutrition Reviews. 2006. 64.5 250-56.

Peterson, Spencer A., Van Sickle, John, Herlihy, Alan T., and Hughes, Robert M. Mercury Concentration in Fish from Streams and Rivers Throughout the Western United States. Environmental Science \& Technology. 2007. 41.1 5865.

United States Environmental Protection Agency. Human Health Criteria Development Documents. Accessed 27 February 2017. Available at https://www.epa.gov/wqc/human-health-criteria-developmentdocuments.

United States Environmental Protection Agency. National Listing of Fish Advisories Questions and Answers 2011. Accessed 19 July 2017. Available at https://www.epa.gov/fish-tech/national-listing-fish-advisories-questionsand-answers-2011.

United States Environmental Protection Agency. EPA updates annual list of fish advisories and makes fish advisories available on the internet. Published 08 December 1999. Accessed 19 July 2017. Available at https://archive.epa.gov/epapages/newsroom_archive/newsreleases/ea3a 66fdd3f5bcd3852567cb006cce22.html.

United States Environmental Protection Agency. Clean Water Act Section 303(d): Impaired Waters and Total Maximum Daily Loads (TMDLs). Accessed August 27 2017. Available at www.epa.gov/tmdl.

Vannoy, Jim "Re: Fish consumption advisory inquiry." Message to Alyssa Clayton. 11 August 2016. Personal communication.

Idaho Department of Health and Welfare. The Idaho Fish Consumption Advisory Program. Accessed 27 August 2017. Available at healthandwelfare.idaho.gov/Health/EnvironmentalHealth/FishAdvisories/t abid/180/Default.aspx. 


\section{Appendix A}

Survey questionnaire sent to contacts the Idaho Division of Public Health, Oregon Health Authority and Washington Department of Health.

\section{NAME STATE AGENCY}

Please comment on categories and information in the figure and respond to the following questions. Thank you for your time and help with this project.

1. Long term funding mechanism:

2. State agency partners:

3. Federal agency partners:

4. Number of full time staff monitoring/updating/publishing advisories:

5. Formalized communication/collaboration between agencies:

a) Are there agreements in place to formalize collaboration?

b) Does your agency rely on outside data sources to establish statewide bass consumption advisories, if so is that relationship formalized or on an interpersonal ad hoc basis?

6. Data sharing amongst agencies:

7. Sampling Methodology:

8. Number of data points integrated into bass FCA:

a) What is the minimum number of measurements states rely on to calculate statewide bass consumption advisories?

9. Sampling breadth, survey protocol:

b) Is random sampling employed to prevent bias?

c) How do agencies choose which sites to collect data?

d) Is there a need to have guidelines about sampling?

e) Are there requirements for geographic distribution of sampling for statewide advisories?

10. As an employee with the state, do you have power to negotiate your responsibilities, advocate for public resources and address issues of underfunding to improve public health?

11. Discuss the importance of having a diverse number of perspectives considered in environmental decision making: 